\title{
An Assessment of the Effectiveness of Central Bank Sterilization on Capital Inflows in Nigeria
}

\section{Tijjani M. Jume ${ }^{1}$}

This paper assesses the monetary policy response of the Central Bank of Nigeria $(C B N)$ to increases in capital inflows into Nigeria using monthly time series data from January 2009 to December 2017. It presents an econometric assessment of the degree to which the CBN sterilizes net foreign assets (NFA) in response to the capital flows, using Autoregressive Distributed Lag (ARDL) Bounds testing approach. The long run sterilization coefficient obtained suggests that the CBN successfully offset 95per cent of capital inflows in the period of analysis. Against the background of rising financial instability in Nigeria, the study illustrates how sterilization has not adequately tackled the major risks of capital inflows which resulted in asset price bubbles and bursts, equity capital inflows reversal, banking crisis, and currency depreciation which contributed, partly, to the economic recession in 2016. The paper argues that effective policy response to capital inflows must adequately address the major downside risks of capital inflows in the short and medium terms through some clearly defined capital flows management and macro-prudential measures.

Keywords: Assets price, capital flows, impossible trinity, sterilization

JEL Classification: E52, E58

DOI: $10.33429 /$ Cjas. $11220.8 / 8$

\section{Introduction}

The waves of capital flows to Emerging Market and Developing Economies (EMDEs) ${ }^{2}$ before and after the Global Financial Crisis (GFC) pose strong concerns for financial system stability as well as good prospects for their growth. For instance, in 2007, total capital flows to EMDEs (excluding official flows) was over 1.5 trillion US\$, which was reduced to 0.6 trillion US\$ in 2009 during the GFC (Adrian, 2018). In the aftermath of the GFC, capital flows to EMDEs surged again to 1.5 trillion US\$ between 2010 and 2012 and reduced to 0.5 trillion US\$ in 2013 (Adrian, 2018).

\footnotetext{
${ }^{1}$ Department of Economics, Ahmadu Bello University, Zaria. Kaduna State, Nigeria. Email: tmjume@abu.edu.ng

${ }^{2}$ The IMF defined and listed EMDEs as some 142 countries in 6 regions across the world. This includes Nigeria in the sub-Saharan Africa. See International Monetary Fund's World Economic Outlook Report, October 2012 @ http://www.imf.org/external/pubs/ft/weo/2012/02/pdf/text.pdf, 182-183.
} 
The Nigerian economy, like most EMDEs, is open and had attracted capital inflows since 2005 following financial globalization and the implementation of capital account liberalization reform recommended by the International Monetary Funds (IMF). There is a consensus among economists and policymakers that capital flows could pose serious concerns (This is because countries want to enjoy all the benefits of capital flows while shielding themselves from the likely macroeconomic shocks of these financial flows) from three major risk areas; macroeconomic risks, financial stability risk and sudden reversal of capital flows, particularly, equity capital flows (Adrian, 2018; Calvo, Leiderman \& Reinhart, 1993; Kawai \& Takagi, 2008). Capital inflows could undermine the ability of the Central Bank of Nigeria (CBN) to oversee its primary function of maintaining price stability. Likewise, capital flows could create volatilities in the capital market and trigger sudden reversal of portfolio inflows (equity inflows), banking crises and sharp currency depreciation that could push the economy into a recession.

The fear of the major downside risks of capital surge had necessitated the sterilization policy response from the CBN. Sterilization is the deliberate monetary response by the central bank to tame the potential effects of foreign capital inflows on the domestic money supply mainly through the sale (or purchase) of securities known as open market operations (OMO). The CBN also uses other instruments such as cash reserve requirements (CRR), public sector withdrawal of deposits from Deposit Money Banks (DMBs) as well as some exchange rate flexibility options to sterilize excess liquidity.

This study is motivated by the dearth of studies on monetary policy response to capital flows to Nigeria. Given the openness of the Nigerian economy to capital flows, particularly after the GFC, to the best of our knowledge, there is no study that investigated the CBN's monetary sterilization policy except Okpanachi (2012) which did not evaluate the CBN's sterilization policy along the lines of each of the downside risks of capital flows. Also, the scope of his analysis was restricted to the period 2000 to 2011, using simple Ordinary Least Squares (OLS) regression analysis. This study attempts to fill the gap in the literature by making two key contributions. First, it expands the literature by using the ARDL Bounds test approach to cointegration to analyze the CBN sterilization response to capital inflows in Nigeria. Secondly, it presents an empirical evaluation of sterilization policy in tandem with each of the downside risks of capital flows which previous study failed to do. 
The objective of this study, therefore, is to assess the effectiveness of the CBN's sterilization of capital flows to Nigeria from 2009 - 2017 using monthly data and adopting the Autoregressive Distributed Lag (ARDL) Bounds test approach to cointegration. In addition to estimating the sterilization coefficient, the study empirically evaluates the CBN sterilization response in the context of the major risks of capital flows.

The paper is organized into 5 sections as follows: Section 2 reviews the empirical and theoretical literature. In Section 3, data and methodology of the study are presented. Section 4 presents and discusses the results while Section 5 concludes the paper and presents policy recommendations.

\section{Literature Review}

The literature review is divided into two parts. The first part reviews the theoretical literature from which the theoretical framework of the study emerged. The second part reviews the available empirical literature for Nigeria and also a number of country-specific and crosscountry studies.

\subsection{Theoretical Literature}

The basis of any theoretical discussion on monetary sterilization policy in an open macroeconomic framework must begin with the analysis of capital account deregulation policy which allows free flows of capital between nations. Capital flows are divided into; debt, portfolio equity, foreign direct investment (FDI) and cross-border real estate investments that are recorded in the capital account of the balance of payments. Capital outflows include; purchases of foreign assets and repayment of foreign loans by residents (Eichengreen, et al. 1999).

According to Haberer and Lux (2012), as well as Rajan and Subramanian (2005), the potential problems to free capital mobility are clustered around 4 issues. First is the fear of currency appreciation in terms of currency exports competitiveness, causing decline in exports. Where the currency is defended by the Central Bank to prevent appreciation, excess money supply can cause inflationary pressure. Second is the issue of 'hot money'; a sudden injection of capital in form of portfolio inflows into small open markets like EMDEs, can cause initial dislocation. There is also the fear of sudden withdrawal, which depreciates the currency and destabilizes markets. Third is the fear that large volumes of capital inflows in 
search for higher yields can cause the dislocation of the financial system. It can also fuel assets price bubbles, encouraging excessive risk taking by commercial banks. The last is the fear of loss of monetary policy sovereignty, without which exchange rate stability, monetary policy autonomy and capital account deregulation would not be possible.

Mundell (1963) and Fleming (1962), hereafter M-F, postulated an important static general equilibrium approach that portrays the short-run relationship between nominal exchange rate, interest rate, and output in a small open economy. The model using the IS-LM-BOP framework predicts that macroeconomic policy choices in open economies are constrained by the trilemma; that an economy cannot simultaneously maintain three desirable but contradictory macroeconomic objectives. The simultaneous pursuit of these three objectives could lead to financial and banking crises. Specifically, the principle of the impossible trinity suggests that only 2 of the following policies can be pursued at any given time:

(i) Fixed (Stable) Exchange Rate: Facilitates engagement and future planning of exports and imports and hence is important in boosting domestic and international trades.

(ii) Independent (Sovereign) Monetary Policy: This is an economy stabilizer and can be used to address recession and inflation. Central banks can vary money supply and interest rates according to the economic cycle to achieve growth and stability.

(iii) Capital Account Deregulation: Makes the country's economy open to international capital flows which encourage foreign investors to bring resources and expertise into the country for investment and growth. Under capital account deregulation, the domestic interest rate equals the world interest rate and so there is no possibility for independent monetary policy.

Calvo, Leiderman and Reinhart (1993), and Reinsen (1993a, 1993b) built on the M-F framework to contest the sustainability of monetary policy response to capital flows. Briefly put, the major argument posted by Calvo et al. (1993) suggests that under free capital mobility regime, it is not sustainable for a central bank to sterilize capital inflows because the policy tends to perpetuate a high domestic-foreign interest rate differential which gives rise to repeated rounds of capital inflows. These rounds of capital inflows imply increased fiscal cost to sterilize them which becomes unsustainable over time. On the other hand however, Reinsen (1993a, 1993b) posited that sterilization is possible and easier under a condition of limited perfect mobility of capital, which in practice, some EMDEs managed by using the 
trilemma framework and successfully sterilized capital inflows in their countries. Frankel (1994) reviewed these arguments and concluded that a successful application of sterilization intervention can be achieved under the standing assumptions of the two different models.

\subsection{Empirical Literature}

There is a large number of empirical studies on sterilization policy across the EMDEs particularly in Asia, Europe, North America and some parts of Africa. In sub-Saharan Africa however, there is a dearth of empirical studies that investigated the monetary sterilization policy. For instance, in Nigeria, to the best of our knowledge, apart from the work of Okpanachi (2012), there are no other studies that investigated the CBN sterilization index. Because of this literature gap, our review of empirical literature on Nigeria is built entirely on Okpanachi (2012) and complemented with some similar studies drawn across other EMDEs to fill the literature gap. The review of the empirical literature is based on the methodology/findings by the authors.

The first group of empirical studies that investigated the sterilization response to capital inflows includes, inter alia, Okpanachi (2012), Khushk, Gilal and Taherani (2015), and Cardarelli et al. (2010). These studies used econometric techniques such as simple Ordinary Least Squares (OLS) method, 2 Stage Least Squares, instrumental variables and pooled OLS to estimate the sterilization coefficient. For instance, Okpanachi (2012) used the simple OLS to investigate the response of CBN to capital flows in Nigeria using monthly data for the period 2000 - 2011. The study estimated the sterilization coefficient to be -0.69 for the equation with NDA as dependent variable and when broad money (M2) was used, the coefficient remained -0.69 . The study found no attempt by the CBN to smooth sterilization over time but Sterilization coefficients for all the rolling regressions were statistically significant, suggesting that the CBN sterilized NFA throughout the sample period with varied intensity. Khushk et al. (2015) used instrumental variables method to estimate the sterilization coefficient for Pakistan over the period 1982 - 2013. The results suggest that the central bank sterilized 35 per cent of capital inflows during the period, indicating that the changes in net domestic assets were fully offset by equal and opposite direction changes in net foreign assets. In addition, estimates of the real exchange rate were positive showing that an increase in real exchange rate resulted in an increase in net domestic assets. Cardarelli et al. (2010) used pooled OLS regression technique to examine the macroeconomic implications and policy re- 
sponse to surges in capital across 52 emerging and developed economies from 1987 - 2007. The authors developed a sterilization index for the 52 countries using the NDA equations. They also used a broader measure of liquidity M2 equation, given the fact that countries also used reserve requirements to cushion the effects of capital flows. Results of the investigation revealed a high sterilization index for the countries under study. The study also found episodes of large inflows, but appropriate policy responses depended on country-specific circumstances including the nature of flows.

The second group of studies includes, among others, Chung et al. (2014), Christensen (2004), Moreno (1996), Tagaki and Esaka, (2001), Ouyang and Rajan (2005). These studies used multi-equations models such as simultaneous equation models and Vector Autoregressive (VAR) Models. For example, Chung, et al. (2014) used simultaneous equation model based on microeconomic framework to investigate sterilization coefficient in China and also the sustainability of the sterilization policy in the wake of China's gradual shift towards market-oriented policies and globalization, including high volume of foreign exchange reserves which constituted about 70 per cent of the Peoples Bank of China's total assets as at 2012. Using the 2 stage least squares method, the results of the study which estimated the 2 equations of NDA and NFA show -0.717 and -0.831 , respectively. These results indicate that 70 per cent of the change in net domestic assets of the central bank was offset by a negative change in the net foreign assets and 80 per cent of the change in net foreign assets of the central bank was offset by a negative change in net domestic assets. Therefore, sterilization was effective. Analysis of the sustainability of sterilization policy indicates that the sustainability of the sterilization policy was challenged by high cost of policy.

Christensen (2004) used a VAR model that incorporated domestic credit, foreign exchange reserve, domestic interest rate, foreign interest rate to analyze the relationship between capital inflows and sterilized intervention in Czech Republic from 1993 to 1996. The study found sterilization of capital inflows successful in controlling the influence of foreign exchange reserve inflows initially. However, over time, increased domestic interest attracted more capital inflows, which commercial banks were entangled in "sterilization game" with the central bank: - a situation where the banks borrowed money from foreign banks and invested them in domestic bonds. The rise in domestic interest on bonds increased the cost of sterilization which became unsustainable for Czech Republic in the long run. Similarly, Moreno (1996) 
used 4 variable VAR to investigate the degree of response of monetary policy to foreign assets in Korea and Taiwan using monthly data from 1981M1-1994M12. The study found sterilization in both countries effective in addressing foreign assets shocks with varying degrees. For instance, Korea's response to foreign assets was more effective than Taiwan's. Takagi and Esaka (2001) investigated sterilization response to capital flows to Thailand, Indonesia, Korea, Malaysia and the Philippines using structural equation models. Results from the OLS estimation of the structural equations reveal that sterilization policy was effective in all the countries and more importantly, the sterilization attempt did not spur interest rate hike, contrary to some findings that sterilization accelerates the rise in interest rates thereby making the policy costly and unsustainable (Calvo et al., 1993, Christensen 2004 ). Ouyang and Rajan (2005) assessed the de facto extent of monetary sterilization by estimating a set of simultaneous equations derived from an optimizing framework that reveals the relationship between net domestic assets and net foreign assets. Results of the investigation showed that China was actively involved in sterilization of capital flows since 1990. Apart from the rising cost of sterilization, which was high and becoming unsustainable, capital flows to China were also increasing, especially in 2003-2004. The study suggested that the Peoples Bank of China could reduce the monetary base directly by increasing the reserve requirements of commercial banks which may generate low-to-zero returns.

The third group of studies comprises studies like Djedaiet and Ayad (2017), Hashmi et al. (2011), Qayyum and Khan (2003). These studies used assorted cointegration techniques like Engel-Granger (1987), Johansen and Juselius (1990) and Autoregressive Distributed Lag (ARDL) of Pesaran and Shin (1999) to investigate the effectiveness of sterilization policy response to capital flows. For instance, Djedaiet and Ayad (2017) explored the degree to which the Bank of Algeria sterilized hard currency inflows using monthly data from 20022016. Using the ARDL econometric technique, the study estimated the long run sterilization coefficient to be -0.99 (close to -1.0), indicating that the Algerian central bank sterilized 99 per cent of the hard currency inflows during the period of analysis. This revealed that the adjustment is instantaneous. Hashmi et al. (2011) used Johansen multivariate cointegration technique to estimate monetary policy reaction function and degree of sterilization for countries comprising Pakistan, Korea, Philippines and Japan by using quarterly data from 1980:Q1 to 2007:Q2. The long run sterilization coefficient for Pakistan, Japan, Korea and 
Philippines were estimated to be $0.83,0.61,0.26$ and 0.56 respectively. Adjustment of short term towards long run equilibrium varied among the samples, suggesting differences in the level of policy pursuit as well as development of the financial systems. Qayyum and Khan (2003) investigated monetary policy intervention response to capital inflows in Pakistan for the period 1982Q3 to 2001Q2. Using Johansen multivariate cointegration technique, the study estimated the long run sterilization coefficient to be 0.72 , suggesting that 72 per cent of the capital flows were sterilized by the central bank. The results of the error correction model indicate that about 88 per cent sterilization took place in the short run, indicating that the short run sterilization coefficient is greater than the long run coefficient.

An evaluation of the empirical literature reviewed on most EMDEs reveals that most studies assess the effectiveness of sterilization in terms of size, intensity and theoretical expectations of the coefficient, with no attempt to evaluate the effectiveness of monetary sterilization against the major risk of persistent capital inflows. This approach appears to be weak because most studies found a high degree of monetary sterilization intensity in the wake of increasing financial vulnerabilities associated with capital flows. For instance, in his analysis of the sterilization policy response to capital inflows in Nigeria, Okpanachi (2012) found evidence of less-than-full, but significantly high sterilization intensity. This finding is consistent with similar studies in EMDEs including Qayyum and Khan (2003) for Pakistan and Djedaiet and Ayad (2017) for Algeria. However, the study did not demonstrate whether the high sterilization intensity was effective or not in preventing the risks of inflationary pressures, asset price bubble and capital reversal from crystalizing in Nigeria.

Similarly, an in-depth review of the methodology and estimation techniques used by most of the studies reveals the existence of some weaknesses with the estimation techniques. For instance, simultaneous equation models are susceptible to endogeneity problems (Glick \& Hutchison 2000). On the other hand, cointegration techniques like Engel-Granger (1987), Johansen and Juselius (1990) are superior econometric techniques but they are based on variables that are integrated of the same order $I(1)$. If the variables are integrated of different orders like $I(1)$ and $I(0)$ or $I(2)$, the use of Engel-Granger (1987) or Johansen and Juselius (1990) co-integration is not tenable.

Against these weaknesses, this study adopts the ARDL cointegration econometric technique which overcomes the weaknesses identified with other competing techniques like Engel- 
Granger (1987), Johansen and Juselius (1990). For instance, the ARDL has advantage over these co-integration models by testing the long-run relationship among variables irrespective of the order of integration (except variables of $I(2)$ ) in both large and small samples and the major advantage of this lies in its identification of the cointegrating vectors where there are multiple cointegrating vectors (Nkoro \& Uko 2016). It also removes problems of endogeneity, omitted variables and autocorrelation associated with structural equation or simultaneous equation models (Pesaran et al., 2001; Pesaran \& Shin, 1998).

\subsection{Stylized Facts}

The trend in capital flows to Nigeria shows that Foreign Direct Investment (FDI) and portfolio equity flowed gradually into the country and reached 8.8 billion US\$ and 1.5 billion US\$, respectively by the end of 2007. However, the GFC in March 2008 reversed the equity capital flows to negative (-959.79 million US\$) (CBN Statistical Bulletins, 2015) but the FDI component managed to remain at 8.2 billion US\$. However, in the post-GFC period, capital surged again to reach an all-time high in 2012 when total capital flows and net equity inflows stood at 24.33 billion US\$ and 10.03 billion US\$, respectively. By the end of 2012, equity flows began to reverse again and nose-dived to a negative position of -476.62 million US\$ in 2015. From the trend in capital inflows, equity capital surged and reversed consistently to record two episodes of net outflows, first, in 2008 and secondly, in 2015. The trend, timing and volatility of capital flows in Nigeria correlate significantly with the global trend, timing and volatility of capital flows, suggesting the presence of systemic risk in the global financial system.

The behavior of net domestic assets (NDA) and net foreign assets (NFA) in Nigeria, particularly from 2008 to 2014 reveals the extent to which the CBN intervened to sterilize capital surge. The trend clearly reveals that when NFA was rising, NDA was declining. For instance, in January, 2012, the NFA was 7,413,617 million against the NDA which stood at 6,341,676 million. When the NFA increased to $7,692,059$ in April the same year, NDA decreased to $5,612,725$ million. Similarly, in September 2013, the NFA increased to $N$ $8,923,526$ million while the NDA decreased to 5,438,925 million. The inverse trend of NDA and NFA suggests that CBN sterilized a portion of capital inflows in Nigeria. However, after 2014, the trend had reversed as illustrated by Figure1. 


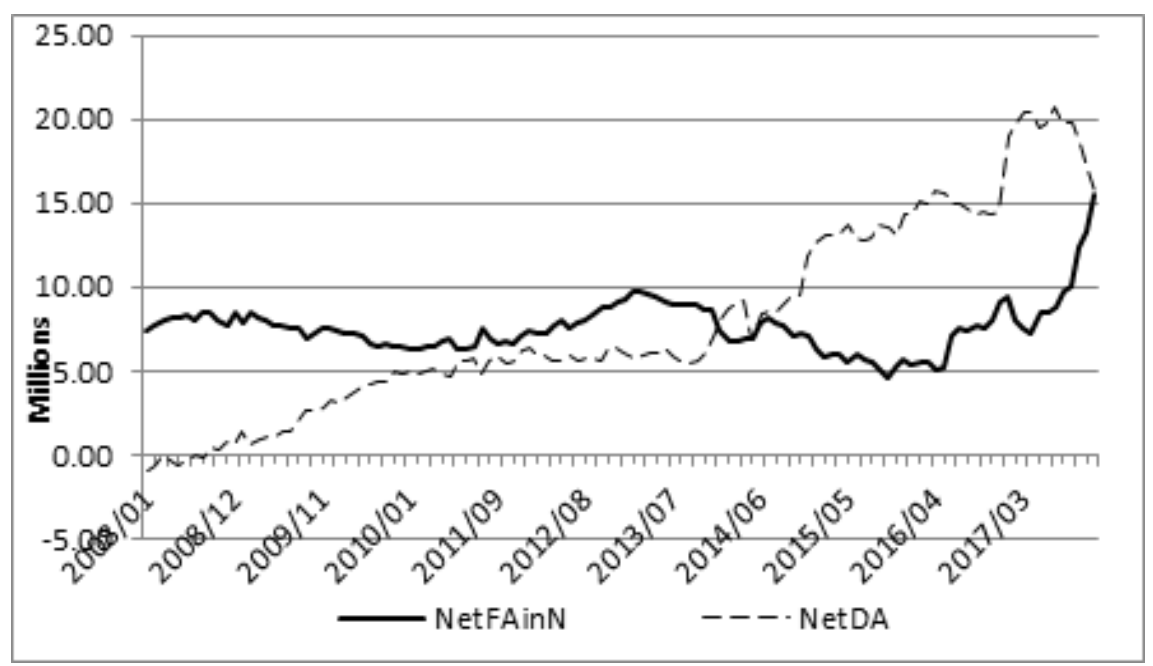

Figure 1: Trend in NDA and NFA 2008- 2017.

\section{Data and Methodology}

\subsection{Data}

This study will use monthly data from 2009:M1 to 2017:M12 (108 observations). NDA is the net domestic assets, NFA is the net foreign assets, INT is the interest rate proxied by treasury bills rate (TBrate), REER is real effective exchange rate (calculated as a weighted average of real exchange rates of the national currency to the currencies of its main trading partners ${ }^{3}$ ), and MM is the money multiplier which is defined as reserves divided by broad money (M2). All the data were obtained from various issues of the CBN statistical bulletin.

\subsection{Theoretical Framework}

This study adopts the Mundell-Fleming theory of 'impossible trinity' as its theoretical framework. According to the Mundell-Fleming theory, the Central Bank cannot pursue and successfully achieve all the three macroeconomic policy objectives simultaneously; exchange rate stability (fixed (stable) exchange rate regime), monetary independence (monetary policy to address domestic recession and inflation) and capital account deregulation (free capital flows). The theory however, postulates that the Central Bank can choose and pursue successfully, a combination of two out of the three macroeconomic objectives simultaneously. The three choices are: (1), A fixed exchange rate and free capital flows (but not an independent

\footnotetext{
${ }^{3}$ The countries are: Brazil, China (Mainland), France, Germany, India, Belgium, Italy, Ghana,
} South Africa, Netherlands, Spain, United Kingdom and United States of America. 
monetary policy). (2), An independent monetary policy and free capital flows (but not a stable exchange rate), and (3), A fixed exchange rate and independent monetary policy (but no free capital flows, which would require some capital control measures).

Given the identified gaps in the empirical literature, particularly in terms of methodology, data and scope of analysis, this study adopted the ARDL bounds testing approach to estimate the extent of sterilization intervention of the CBN to capital flows into the Nigerian economy. The versatility of ARDL cointegration technique in estimating relationship between stationary and non-stationary variables as well as reconciling the short run dynamics with long run equilibrium is most appealing in empirical research. Also, economic theories are based on long run equilibrium between variables. Co-integration is a powerful way of detecting the presence of steady state equilibrium between variables (Nkoro \& Uko, 2016).

In the extant literature, monetary policy reaction function is the standard model used for the estimation of sterilization coefficient. This study adopts the net capital flows equation approach originally used by Kouri and Porter (1974) which was adopted by some recent studies such as Djedaiet and Ayad (2017), Khushk et al. (2015), and Hashmi et al. (2011), among others, to estimate the sterilization coefficient.

\subsection{Model Specification}

Following Kouri and Porter (1974), the monetary policy reaction function is captured by:

$$
\Delta N D A_{t}=\alpha_{0}+\beta \Delta N F A_{t}+\gamma X_{t}+\mu_{t}
$$

where $\Delta \mathrm{NDA}_{t}$ is change in net domestic assets over time $\mathrm{t} ; \Delta \mathrm{NFA}_{t}$, is change in net foreign assets over time $t, X_{t}$ are other determinants of net domestic assets over time t. $\beta$ is the sterilization coefficient, $\Delta$ is the first difference operator, while $\gamma$ is a vector of coefficients of other explanatory variables in the model.

Okpanachi (2012), and Cardarelli et al. (2010) argued that the use of net domestic assets as dependent variable in equation 1 is analogous to the estimation of sterilization coefficient in a narrow context. They argued that in practice, the Central Bank could also raise reserve requirements to sterilize the impact of net foreign assets on money supply. Based on this argument, the studies suggested the use of $\Delta \mathrm{M} 2$ as a dependent variable; M2 is a broader measure of liquidity. Therefore, in this study, both $\Delta \mathrm{M} 2$ and $\triangle N D A$ will each be used as dependent variable to compare their performances in the estimation of the sterilization 
coefficient. Equation 1 can then be re-specified as:

$$
\Delta M 2_{t}=\alpha_{0}+\beta \Delta N F A_{t}+\gamma X_{t}+\mu_{t}
$$

According to Nkoro and Uko (2016), the general ARDL $(p, q)$ approach can be stated as:

$$
\begin{aligned}
& y_{t}=\varphi_{1} y_{t-1}+\ldots \ldots+\varphi_{p} y_{t-p}+\psi_{0} X_{t}+\psi_{1} X_{t-1} \ldots \ldots+\lambda_{1} X_{t-p}+\mu_{1 t} \\
& t=1,2,3 \ldots T \quad \mu_{t} \sim \operatorname{iid}(0, \sigma 2) .
\end{aligned}
$$

Using equations 1 and 2, and applying the ARDL approach to cointegration in equation 2, we state our ARDL (p, q) equation 4 for the estimation of the central bank sterilization coefficient:

$$
\begin{aligned}
\Delta N D A_{t}= & \alpha_{0}+\sum_{i=1}^{n} \alpha_{1 i} \Delta N D A_{t-i}+\sum_{i=0}^{n} \alpha_{2 i} \Delta I N T_{t-i}+\sum_{i=0}^{n} \alpha_{3 i} \Delta M M_{t-i} \\
& +\sum_{i=0}^{n} \alpha_{4 i} \Delta N F A_{t-i}+\sum_{i=0}^{n} \alpha_{5 i} \Delta R E E R_{t-i}+\beta_{1} N D A_{t-1}+\beta_{2} I N T_{t-1} \\
& +\beta_{3} M M_{t-1}+\beta_{4} N F A_{t-1}+\beta_{5} R E E R_{t-1}+\varepsilon_{t i}
\end{aligned}
$$

where $\mathrm{NDA}_{t}$ is net domestic assets over time t, INT is interest rate, MM is the money multiplier, NFA is net foreign assets, REER is the real effective exchange rate. $\Delta$ is the first difference operator. $\varepsilon_{t i}$ is the error term. $\beta_{4}$ is the sterilization coefficient and the a priori expectation is: $-1 \leq \beta_{4} \leq 0$. If it is -1 , it implies full sterilization. If it is 0 , there is no sterilization. When it is between 0 and -1 , it is partial sterilization.

The ARDL model is estimated using variables in their levels (non-differenced data) form. The lags of the variables are alternated, model re-estimated and compared (Nkoro \& Uko 2016). Akaike Information Criteria (AIC) and Schwarz Criterion (SBC) are used for model selection. The selected ARDL model equation is estimated using Ordinary Least Squares (OLS) to enable us to test for long run cointegration of the coefficients through $F$ - statistic (Wald test) based on equation 5 .

$$
N D A_{t}=\alpha_{1} I N T_{t}+\alpha_{2} M M_{t}+\alpha_{3} N F A_{t}+\alpha_{4} R E E R_{t}+\varepsilon_{i}
$$

where the explanatory variables in their log form are defined as before. The parameters of the variables to be estimated are; $\alpha_{1}, \alpha_{2}, \alpha_{3}$ and $\alpha_{4}$. The long-run relationship among the variables is tested by computing the Bound $F$-statistic. The $F$-statistic allows us to know 
whether the variables of the model are co-integrated or not, given the dependent variable. The test has the null hypothesis; $\mathrm{H}_{0}=\alpha_{1}=\alpha_{2},=\alpha_{3}=\alpha_{4}=0$ (no co-integration between the variables) against the alternative hypothesis, $\mathrm{H}_{1} \neq \alpha_{1} \neq \alpha_{2} \neq \alpha_{3} \neq \alpha_{4} \neq 0$ (there is co-integration between the variables). The decision rule as suggested by Pesaran et al. (2001) is that, if the estimated Wald test value ( $F$-statistic value) is higher than the upper bound critical value, the null hypothesis is rejected which signifies the presence of a long run relationship. However, if the estimated $F$-statistic value is less than the lower critical value, the null hypothesis cannot be rejected, suggesting that no co-integration exists among the variables. The condition for the application of the Bounds test in equation 5 is that variables should be $I(1)$ or a combination of $I(0)$ and $I(1)$, but none should be $I(2)$. The number of optimum lag is based on information criteria, AIC or SBC. The best performed model provides the estimates of the Error Correction Model (ECM). The specification of the Error Correction Model (ECM) enables us to have both long-run and short-run coefficients of the variables. The coefficient of the error correction term (ECT) reveals the speed at which short term disequilibrium errors are corrected. A positive coefficient indicates a divergence, while a negative and significant coefficient indicates convergence. The ECM to be estimated is:

$$
\begin{aligned}
\Delta N D A_{t}= & \alpha_{0}+\sum_{i=1}^{n} \alpha_{1} \Delta N D A_{t-i}+\sum_{i=1}^{n} \alpha_{2} \Delta I N T_{t-i}+\sum_{i=1}^{n} \alpha_{3} \Delta M M_{t-i} \\
& +\sum_{i=1}^{n} \alpha_{4} \Delta N F A_{t-i}+\sum_{i=1}^{n} \alpha_{5} \Delta R E E R_{t-i}+\beta_{1} N D A_{t-1}+\beta_{2} I N T_{t-1} \\
& +\beta_{3} M M_{t-1}+\beta_{4} N F A_{t-1}+\beta_{5} R_{E E R_{t-1}+\lambda E C T_{t-1}+\mu_{t}}
\end{aligned}
$$

where the variables are defined as before. ECT is the error correction term and $\lambda$ is the adjustment coefficient.

\section{Result and Discussions}

\subsection{Descriptive Statistics and Correlation Matrix}

Table 1 presents the summary statistics of the variables used in the study. The table describes the basic features of the data over the period 2009:M1 to 2017:M12. The variable with the highest mean is NDA with a value of 8,845,230 while the standard deviation has the value $5,469,410$ suggesting a spread in the variable. 
Table 1: Summary Statistics, using the observations 2009:01 - 2017:12 (108 observations)

\begin{tabular}{llllll}
\hline Variable & NFA & NDA & REER & INT & MM \\
\hline Mean & 7541520 & 8845230 & 82.3058 & 9.47222 & 0.127357 \\
Median & 7409290 & 6120690 & 84.0186 & 10.15 & 0.139038 \\
Minimum & 4622150 & 666728 & 62.1545 & 1.04 & 0.0171408 \\
Maximum & 15520800 & 20745900 & 100.225 & 100.225 & 0.236469 \\
Std. Dev. & 1608600 & 5469410 & 10.6988 & 3.91817 & 0.0700887 \\
C.V. & 0.213299 & 0.618347 & 0.129988 & 0.413649 & 0.550331 \\
Skewness & 1.68042 & 0.628514 & -0.0551782 & -0.524744 & -0.0626687 \\
Ex. Kurtosis & 5.85231 & -0.742432 & -1.3216 & -0.85782 & -1.3536 \\
5\% & 5334660 & 1368650 & 65.745 & 2.308 & 0.023723 \\
95\% & 9743800 & 19779500 & 98.0603 & 14.512 & 0.23359 \\
IQ range & 1728980 & 8567300 & 19.5063 & 6.1775 & 0.140505 \\
\hline
\end{tabular}

A close examination of other variables in the table indicates that the variable with lowest mean and standard deviation is MM with values of 0.1274 and 0.07 respectively. NDA also has the highest range of 20,079,172, indicating some volatility trend of the variable over the period of analysis.

Table 2: Correlation Matrix using the observations 2009:01 - 2017:12

\begin{tabular}{|c|c|c|c|c|c|}
\hline NFA & NDA & REER & INT & MM & \\
\hline \multirow[t]{5}{*}{1} & 0.0883 & 0.1263 & 0.3411 & -0.0083 & NFA \\
\hline & 1 & -0.3537 & 0.4941 & 0.6165 & NDA \\
\hline & & 1 & -0.3177 & -0.8355 & REER \\
\hline & & & 1 & 0.4313 & INT \\
\hline & & & & 1 & MM \\
\hline
\end{tabular}

Table 2 shows the correlation coefficient between the variables in the study. It also shows the strength of association between all the variables using the actual data values. The correlation matrix shows positive relation of NDA with NFA, INT and MM and negative relation with REER.

\subsection{Unit Root Test}

The application of the ARDL model requires the order of integration of variables to be $I(1)$ or a combination of $I(0)$ and $I(1)$, but not $I(2)$. Table 3 reports the results of the Augmented Dickey-Fuller (ADF) and Kwiatkowski-Phillips-Schmidt-Shin (KPSS) tests conducted on the variables included in the model. 
Table 3: Augmented Dickey-Fuller (ADF) and Kwiatkowski-Phillips Schmidt-Shin (KPSS) Tests

\begin{tabular}{lllllll}
\hline \multirow{3}{*}{ Variable } & \multicolumn{2}{l}{ ADF (with trend) } & \multicolumn{4}{l}{ KPSS* (with trend) } \\
& Level & First Diff. & Decision & Level & First Diff. & Decision \\
\hline NDA & -2.3729 & $-15.480 * * *$ & I (1) & 1.1684 & 0.056 & I(1) \\
NFA & -0.0207 & $-8.9358 * * *$ & I (1) & 0.1596 & 0.1575 & I(1) \\
REER & -1.7251 & $-9.7343 * * *$ & I (1) & 0.4016 & 0.0472 & I(1) \\
INT & -2.0762 & $-8.8607 * * *$ & I (1) & 0.2875 & 0.0383 & I(1) \\
MM & -3.2051 & $-13.744 * * *$ & I (1) & 0.3827 & 0.0821 & I (1) \\
\hline
\end{tabular}

KPSS critical value at $1 \%=0.216$, value at $5 \%=0.148$, value at $10 \%=0.120$

ADF Critical Values (Level) : $1 \%=-3.04,5 \%=-2.75,10 \%=-2.61$

ADF Critical Values (1st Difference): $1 \%=-2.99,5 \%=-2.73,10 \%=-2.59$

*** implies statistical significance at $1 \%$ level.

Source: Author's computation using Gretl

Table 3 shows that all the variables are $I(1)$, at 1 per cent level of significance based on the ADF and KPSS tests. This result supports our application of the ARDL bounds testing approach to this study.

\subsection{ARDL Cointegration Bounds Test}

Table 4 shows results of the ARDL Bounds Test. The value of $F$ statistic, $(\mathrm{F}=14.41)$ is greater than the upper bound $I(1)$ of the critical values provided by Pesaran et al. (2001) at 1 per cent level of significance, implying that the variables are cointegrated. Specifically, there is a long run relationship between net domestic assets, net foreign assets, real effective exchange rate, treasury bills rate and money multiplier. With this result, we proceed to estimate the appropriate long run model.

Table 4: ARDL Bounds Test Results

\begin{tabular}{lll}
\hline Level of significance & $\mathrm{I}(0)$ & $\mathrm{I}(1)$ \\
\hline $90 \%$ & 2.45 & 3.52 \\
$95 \%$ & 2.86 & 4.01 \\
$99 \%$ & 3.75 & 5.06 \\
$k=4$ & F Stat. $=$ & 14.4102 \\
\hline K is the number of regressors & \\
Critical values are from Pesaran et al (2001). \\
Source: Author's computation using Gretl
\end{tabular}

\subsection{Long Run ARDL Cointegration Model of NDA in Nigeria}

Based on the result of the bounds test in Table 4, the NDA and its determinants are cointegrated. Therefore, we used OLS to estimate equations 4 and 5, which revealed the longrun coefficients of the ARDL cointegration baseline model based on the Akaike Information Criterion (AIC) and Schwarz Criterion (SBI). The optimal model results are presented in 
Table 5. The table shows the results obtained by regressing independent variables on NDA to get sterilization coefficient based on the selected model. The results reveal the lag order selection. The long run and short run analyses of the ARDL cointegration model are based on the selected model.

Table 5: Results of $A R D L(1,0,0,2,2)$ Model selected

\begin{tabular}{lllll}
\hline 1_NDA & Coefficient & Std. Error & t-ratio & p-value \\
\hline Const & 0.720474 & 0.746465 & 0.9652 & 0.33688 \\
1_NFA & -0.365743 & 0.0869001 & -4.2088 & 0.00006 \\
1_NFA_1 & 0.34302 & 0.0945338 & 3.6285 & 0.00046 \\
1_REER & 0.16032 & 0.0890187 & 1.801 & 0.07485 \\
1_INT & -0.0128572 & 0.0138687 & -0.9271 & 0.35622 \\
1_MM & -0.00731243 & 0.0249003 & -0.2937 & 0.76965 \\
l_MM_1 & -0.0405995 & 0.0213615 & -1.9006 & 0.06036 \\
1_MM_2 & 0.0897313 & 0.0223988 & 4.0061 & 0.00012 \\
l_NDA_1 & 0.797832 & 0.054765 & 14.5683 & $<0.00001$ \\
1_NDA_2 & 0.144646 & 0.0564636 & 2.5618 & 0.01197 \\
Mean dependent var & 15.80448 & S.D. dep var & 0.696985 \\
Sum squared resid & 0.610636 & S.E. of reg & 0.079755 \\
R-squared & 0.988029 & Adjusted R-sqd & 0.986906 \\
F(9,96) & 1266.391 & P-value(F) & $1.33 \mathrm{E}-95$ \\
Log-likelihood & 122.8973 & Akaike crit. & -225.7946 \\
Schwarz criterion & -199.1602 & Hannan-Quin & -214.9995 \\
Rho & -0.008997 & Durbin's h & -0.112155 \\
\hline Source: Author's comp
\end{tabular}

Source: Author's computation using Gretl

\subsection{Error Correction Model (ECM) Results}

The short run adjustment coefficient, $\lambda$ is obtained by estimating the error correction model equation 6 which is a dynamic process for the relationship between NDA and its determinants in Nigeria. Table 6 presents results of the ECM.

The results in Table 6 show the long and short runs CBN sterilization coefficients. The long run coefficient shows a value of -0.95 , suggesting that 95 per cent of net foreign capital flows were sterilized by the $\mathrm{CBN}$ while the short run coefficient is -0.46 , showing that 46 per cent of net foreign assets flows are sterilized by the $\mathrm{CBN}$ in the short run. On the other hand, the value of the adjustment coefficient, $\lambda$ is -0.22 .

It possessed the expected negative sign and is statistically significant at 1 per cent level. The value of the adjustment coefficient shows that about 22 per cent of the adjustment towards long-run equilibrium takes place in one month. This also implies that the adjustment towards equilibrium is not instantaneous but converges slowly. The results of the long run model 
in Table 6 show that all the explanatory variables (NFA, REER, INT, MM) are statistically significant, at least, at 5 per cent level. The EC model which captures the short run model also shows that all the explanatory variables are statistically significant at 1 per cent level with the exception of treasury bills rate which turned out to be insignificant. These results are consistent with Okpanachi (2012) for Nigeria and some other studies in Africa and Asia like Djedaiet (2017) for Algeria, Qayyum and Khan (2003) for Pakistan, Takagi and Esaka (2001) for Korea, Thailand, Indonesia, Malaysia and Philippines. The parameters stability tests which are based on plots of CUSUM and CUSUMSQ are reported at the Appendix 1. The plots show that the parameters are stable at 5 per cent level of significance. The model passed all the diagnostic tests which are presented in Appendix 2.

Table 6: Results of ARDL ECM- Model

\begin{tabular}{|c|c|c|c|c|}
\hline$\Delta \_1 \_N D A$ & Coefficient & Std. Error & t-ratio & p-value \\
\hline const & 0.0309425 & 0.0054933 & 5.6327 & $<0.00001$ \\
\hline$\Delta \_1 \_N F A$ & -0.461814 & 0.0433636 & -10.6498 & $<0.00001$ \\
\hline$\Delta \_1 \_$NFA_1 & $2.17 \mathrm{E}-05$ & 0.0407728 & 0.0005 & 0.99958 \\
\hline$\Delta \_1$ REER & 0.159518 & 0.0547651 & 2.9128 & 0.00447 \\
\hline$\Delta \_1 \_I N T$ & -0.004543 & 0.0219293 & -0.2072 & 0.83632 \\
\hline$\Delta \_\mathrm{l} \_\mathrm{MM}$ & -0.0163771 & 0.0122416 & -1.3378 & 0.18415 \\
\hline$\Delta \_1$ _MM_1 & -0.05774 & 0.0119288 & -4.8404 & $<0.00001$ \\
\hline$\Delta \_1 \_$MM_2 & 0.0307163 & 0.0082531 & 3.7218 & 0.00034 \\
\hline$\lambda E C T_{t-1}$ & -0.21812 & 0.0437397 & -4.9868 & $<0.00001$ \\
\hline \multicolumn{5}{|c|}{ Long Run Coefficients } \\
\hline Const & 24.6734 & 8.19544 & 3.0106 & 0.00328 \\
\hline 1_NFA & -0.954232 & 0.480525 & -1.9858 & 0.04971 \\
\hline 1_REER & 1.5599 & 0.774326 & 2.0145 & 0.04656 \\
\hline 1_INT & 0.47951 & 0.187609 & 2.5559 & 0.01205 \\
\hline 1_MM & 0.743019 & 0.144014 & 5.1594 & $<0.00001$ \\
\hline
\end{tabular}

\subsection{Effects of the Use of M2 as Dependent Variable in the Central Bank Sterilization} Function

Table 7 illustrates results of the estimated equation 6 with broad money supply as dependent variable. The results in Table 7 reveal the long and short runs sterilization coefficients based on broad measure of liquidity, M2. The long run coefficient shows a value of -0.13 which is not statistically significant while the short run coefficient is -0.02 and statistically significant. On the other hand, the value of the adjustment coefficient, $\lambda$ is -0.26 and statistically significant at 1 per cent level. The value of the adjustment coefficient shows that about 26 per cent of the adjustment towards long-run equilibrium takes place in one month. This also 
implies that the adjustment towards equilibrium is not instantaneous but converges slowly.

The results of the short run model show that with the exception of real effective exchange rate (which is significant at 10 per cent) all the explanatory variables (NFA, INT, MM) are statistically significant at least, at 1 per cent level. From Table 7, it is evident that the broad money did not perform well compared to the NDA.

Table 7: Results of ARDL ECM- Model with Broad Money Supply (M2)

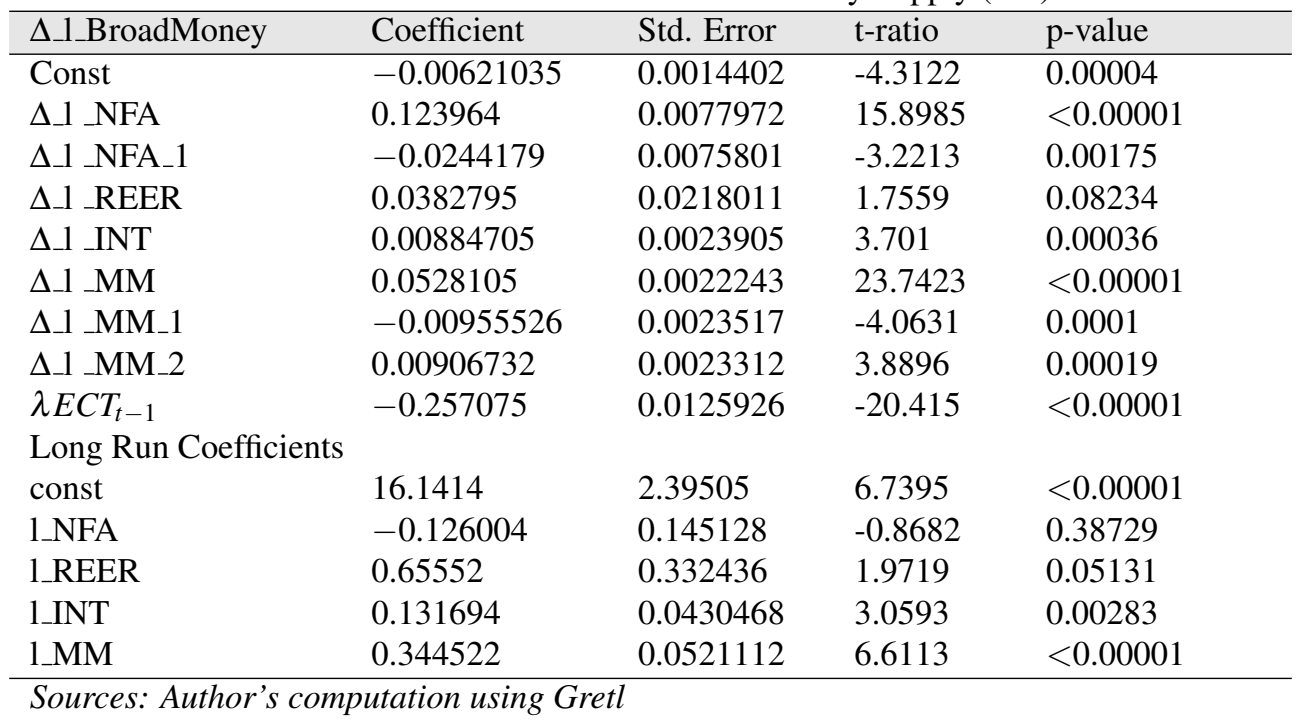

\subsection{Assessing the Effectiveness of CBN Sterilization Response to Capital Inflows in} Nigeria

It is obvious from the literature that previous studies that investigated the effectiveness of sterilization response to capital flows failed to evaluate sterilization policy in terms of the major risks of capital flows to EMDEs. Instead, the studies appeared to have given much emphasis on the effectiveness of sterilization response with respect to sterilization intensity and sustainability. In recognition of this gap, this study evaluated the CBN monetary sterilization response with reference to each of the major risks of capital flows in Nigeria in the period of analysis and logically deduces the conclusions.

\subsubsection{Sterilization Response, Inflation and Real Exchange Rate Appreciation in Nigeria}

Despite the high intensity of CBN sterilization as suggested by the long run sterilization coefficient of -0.95 , inflationary pressures in Nigeria during the period of analysis were of serious concern. For instance, the inflation (year-on-year) was 8.00 per cent in 2013 but increased 
to 9.55 per cent in 2015 . By 2016 it had surged to 18.55 per cent. This outcome is not surprising because the estimated equation 6 with M2 as dependent variable revealed an insignificant long run sterilization coefficient with value -0.13 , suggesting that the sterilization intervention was not effective on broad money supply, M2 which is influential in explaining movements in the price level. In terms of currency appreciation in real terms, Figure 2 shows the relationship between the NDA and the real effective exchange rate in the period 20082017.

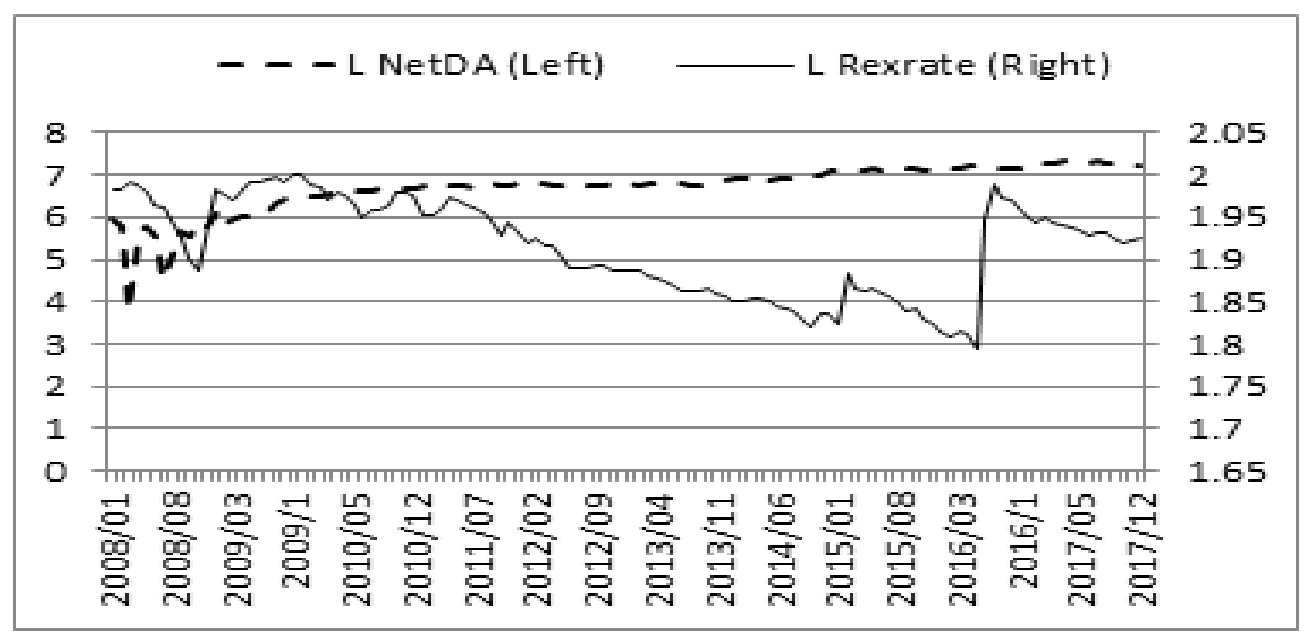

Figure 2: Net Domestic Assets and Real Effective Exchange Rate 2005-2017

The evidence in Figure 2 shows that the naira appreciated from 2009 to the first quarter of $2016^{4}$. When the demand for foreign exchange was increasing rapidly thereafter, the excess demand over supply of foreign exchange at the foreign exchange interbank market and Bureau de Change put pressure on the nominal exchange rate, forcing the $\mathrm{CBN}$ to devalue the currency by allowing the naira to float temporarily which depreciated the exchange rate at the Bureau-de-Change (BDC) Market to 455.26 to a dollar (CBN Statistical Bulletin, 2018) before the Bank intervened again in 2017 to keep the exchange rate within the band of $\$ 360.00$ - 3365.00 to the US \$. For instance, Proshare (2016) reports that at the parallel market, the dollar exchanged for $\$ 422 / \$ 1$ on September 6, 2016 while it moved up to exchange at 446/\$1 as at September 27, 2016.

\footnotetext{
${ }^{4}$ Of course, the CBN maintained the appreciated naira through its intervention in the foreign exchange market where the nation's foreign exchange reserves were used.
} 


\subsubsection{Sterilization Response and Domestic Interest Rate}

This study also examined the effects of sterilization on the interest rate. Sterilization through open market operations (OMO) tends to increase domestic nominal and real interest rates which may increase further capital flows and subsequently makes the policy costly and unsustainable (Calvo et al. 1993). Figure 3 depicts the relationship between sterilization and interest rate proxied by treasury bills rate (TBrate) from 2008-2017.

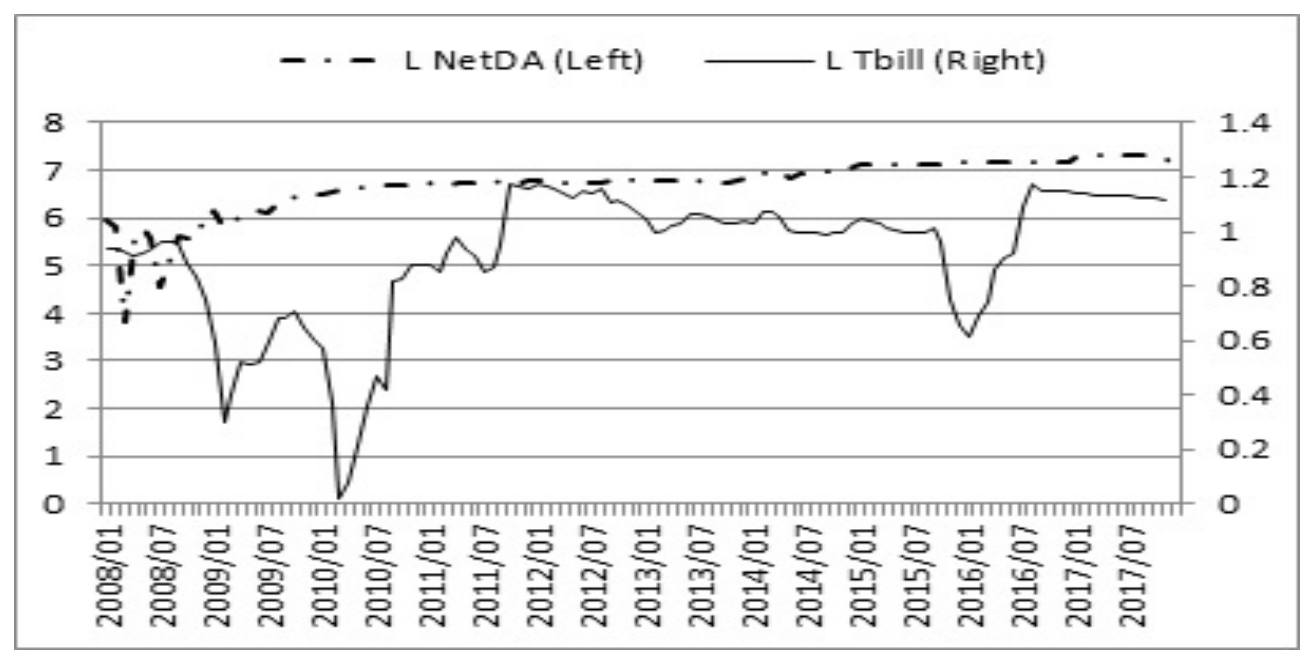

Figure 3: Sterilization and TBrate 2008-2017.

As shown in Figure 3, TBrate fluctuated in the period of analysis. For instance, from 2010 -2012, the rate increased tremendously perhaps due to CBN sterilization through OMO that entailed selling TBs which raised the TBrate. This conclusion is confirmed by Okpanachi (2012). However, the TB rate gradually declined from 2012-2016 as the CBN reduced the sterilization intensity due to the fiscal cost involved and the increasing use of CRR which was a less costly and effective sterilization strategy. However, after 2016, the rate jumped to pre-2012 level due to the rise in the monetary policy rate (MPR) to dampen the inflationary pressure and attract capital inflows to supplement the declining foreign exchange reserves in the wake of declining oil revenue.

The CBN's attempt to sterilize domestic assets by raising and segmenting ${ }^{5}$ the cash reserve ratio (CRR) has implications for the money multiplier (MM). Figure 4 reveals the relationship

\footnotetext{
${ }^{5}$ The Monetary Policy Committee (MPC) in 2014 raised and segmented the CRR from 12 per cent to 20 per cent ( 75 per cent for public sector) and in 2016 to 22.5 per cent uniformly to control monetary expansion.
} 
between the NDA and the MM in the period of analysis.

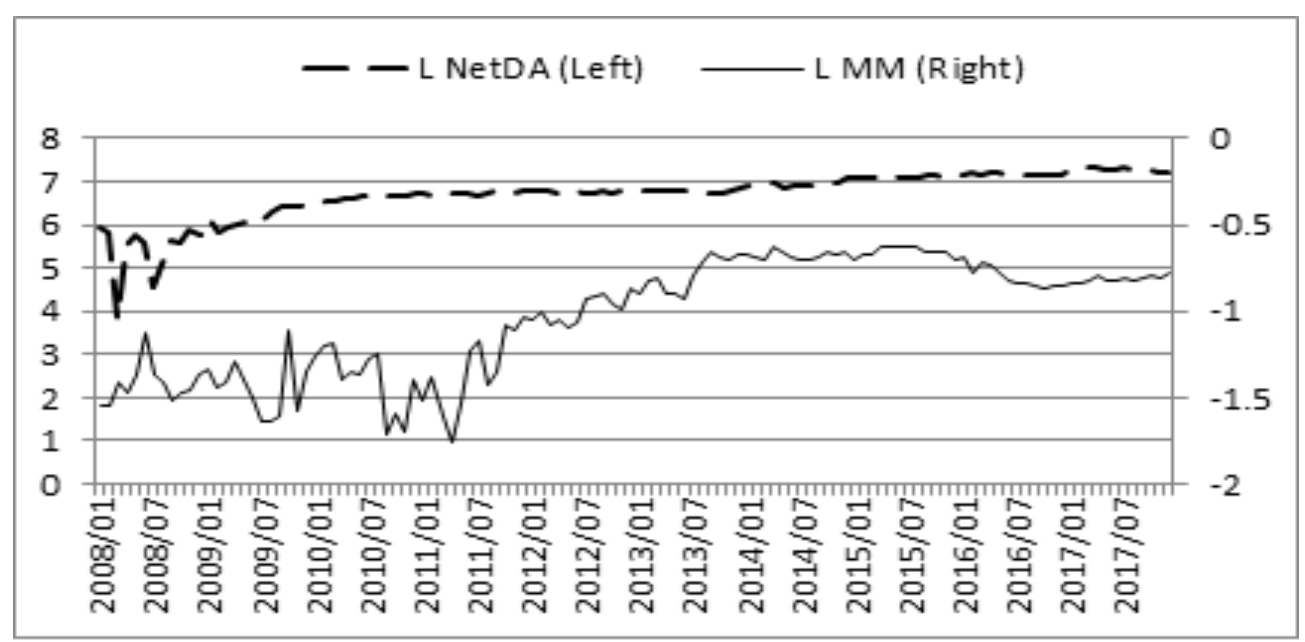

Figure 4: Net Domestic Assets (NDA) and Money Multiplier (MM)

From Figure 4, we observe that MM was rising from 2011 to 2014. This was the period when the CBN maintained the CRR fixed at 12 per cent while sterilization intensity was reduced until 2014, when the CBN raised the CRR to 14 per cent and subsequently 22.5 per cent, marking the gradual decline in MM to control money supply.

\subsubsection{Sterilization Response, Capital Surge and Reversal in Nigeria: 2008-2017}

Figure 5 illustrates the volatility trend of capital flows. It shows two episodes of portfolio capital surge and reversal; the capital surge and reversal in 2008 in the wake of the global financial crisis (GFC) and the one in 2012 were particularly notable. The figure also shows that after the surges, capital reversed in 2008 and 2012 to become negative. These episodes of capital surge and reversal led to asset price bubbles and burst in the Nigerian capital market with losses sustained mostly by domestic investors as well as the rise in banks' non- performing loans (NPLs) which led to banking crises. In addition, the capital reversal contributed to depletion of the nation's reserves and currency depreciation which contributed to the 2016 Nigerian economic recession. 


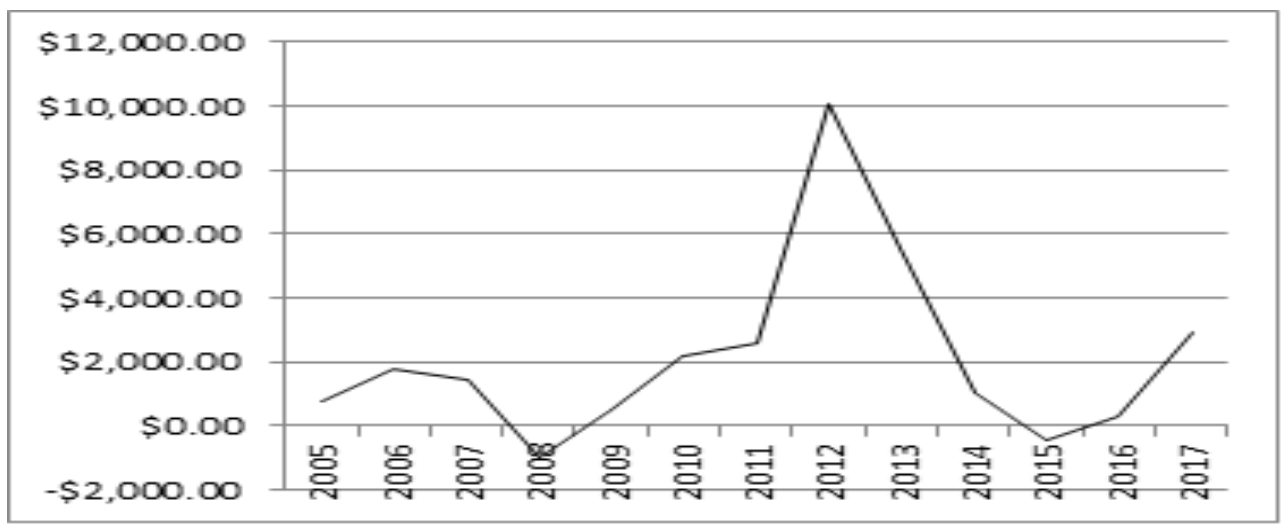

Figure 5: Equity Capital Surge and Reversal

\subsubsection{Sterilization Response, Assets Price Bubble and Burst in Nigeria: 2008-2017}

The Figure 6 shows the fluctuations in the Nigerian Stock Exchange (NSE). It specifically, shows the impact of capital flows on the NSE which created asset price bubbles despite the high sterilization response by the CBN to the inflows. The capital inflows raised stocks prices from 2006 leading the appreciation of the All Share Index (ASI) in the market to 600,000 points in 2007. The GFC in March, 2008 burst the bubble and crashed the stock market prices as evidenced by the sharp decline in All Share Index (ASI) to 20,000 points. The market remained bearish until 2014 when capital flows surged again to raise the ASI to 42,000 points. However, in 2016, the NSE market bubble burst again due to crude oil price slump, causing the ASI to fall to 24,000 points.

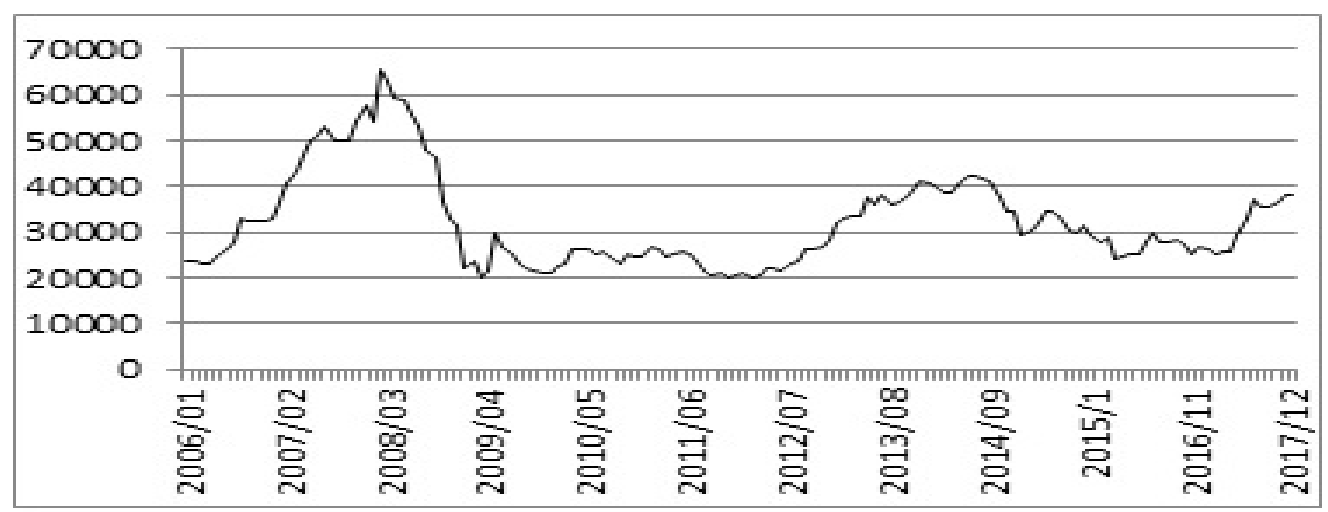

Figure 6: Assets Price Bubble and Burst in the NSE 
From the step-by-step evaluation of CBN's sterilization response to capital flows in Nigeria, it is obvious that sterilization intervention was not effective in cushioning the adverse impact of capital flows in Nigeria. The risk of inflation and currency appreciation were not contained (as the data in Figure 1 show, especially after 2014). Similarly, the risks of capital reversal and assets price bubble and burst escalated as shown in Figures 5 and 6.

\subsubsection{Policy Implications}

From a policy response perspective, capital controls, exchange rate flexibility and monetary sterilization policies are within the CBN purview (Okpanachi 2012). Consequently, the CBN at different occasions used OMO, CRR, public sector withdrawal of deposits from banks as well as some exchange rate flexibility options including foreign exchange swaps to sterilize excess liquidity, which may have achieved some level of success. For instance, when the sterilization intensity was sustained using OMO, from 2010-2012, the TBrate spiked up which caused the CBN to soft-pedal in 2014 and shift emphasis to increased CRR which reduced money supply through the fall in MM. However, the current financial instability suggests that sterilization interventions in Nigeria have not been effective in subduing the risks of capital flows. In view of this outcome, it is instructive that we look closely at the policy contradiction embedded in the Mundel-Fleming theory of 'impossible trinity'.

Recently, in response to increased financial instability in most EMDEs like Nigeria, the IMF's level of support for capital controls has increased (Gallagher \& Tian, 2017). Recent experiences from some EMDEs reveal that the IMF supported the use of capital controls on inflows in a number of EMDEs such as Brazil and South Korea. The support shows clearly that Capital Flow Management (CFM) measures ${ }^{6}$ can be used to effectively subdue the menace of capital particularly the portfolio inflows (equity inflows). For instance, in October 2009, Brazil introduced a 2 per cent tax on portfolio equity and debt inflows, the tax rate increased to 4 per cent for fixed-income investments and equity funds. In 2010, Brazil also raised bank capital requirements for most consumer credit operations with maturities of over 24 months, including car loans. Indonesia, in March 2011 raised reserve requirements on foreign currency accounts from 1 per cent to 5 per cent and this was increased to 8 per cent in June 2011. Indonesia also imposed a six-month holding period on central bank bonds and

\footnotetext{
${ }^{6}$ The Capital flow management measures (CFMs) are certain administrative, tax, and prudential measures that are designed to influence capital inflows (Pradhan et al. (2011)
} 
a limit on short-term foreign borrowing by banks to 30 per cent of capital. In order to limit bank vulnerabilities to inflow volatility, and to reduce incentives for banks to intermediate short-term inflows, withholding tax on foreign holdings of government bonds bills were introduced. Thailand in October, 2010 re-imposed 15 per cent withholding tax for state bonds on foreign investors. Korea in January, 2011 re-introduced 14 per cent withholding tax on foreign holdings of government bonds and central bank securities. Malaysia in 1998 imposed a 12-month waiting period for non-residents to convert proceeds from the sale of Malaysian securities. Thailand in 2008 imposed limits on forward transactions and introduction of export surrender requirements. These measures recorded some levels of successes (IMF, 2011; Nar, 2014).

Given the extreme openness of the Nigerian economy to capital flows, and the level of success recorded in the use of capital control measures in most EMDEs, it is practicable that the Central bank of Nigeria adopts the capital flow management measures (CFMs) used by many EMDEs like India, Brazil, South Korea, Indonesia, Malaysia, and Thailand to complement existing sterilization intervention (OMO, CRR, public sector deposits).

\section{Conclusion and Policy Recommendations}

The paper used ARDL cointegration technique to investigate the CBN policy responses to capital flows to Nigeria from 2008-2017. Results of the estimated model equation 4 revealed a statistically significant long run sterilization coefficient of -0.95 with the expected negative sign, suggesting that the CBN sterilized 95 per cent of the capital inflows during the period. This finding is consistent with Okpanachi (2012). Despite the high intensity of CBN sterilization response, this study documented; a rise in inflationary pressures (particularly after 2014), real exchange rate appreciation, evidence of high cost of sterilization, assets price bubble and burst in the NSE market as well as equity capital reversal during the period of analysis. The policy implication of this outcome suggests that monetary policy sterilization cannot adequately address the major risks of capital inflows in Nigeria. These findings are consistent with Okpanachi (2012), Cardarelli et al. (2010), Ouyang and Rajan (2005), Djedaiet and Ayad (2017) and Qayyum and Khan (2003). Therefore, it is pertinent that we reflect on Mundell-Fleming (1963) macroeconomic policy trilemma: A country must choose to pursue 2 out of the 3 macroeconomic policies; - between free capital mobility, exchange rate management and monetary policy independence. In Nigeria, it appears that all the 3 
choices are pursued by the CBN. First, there is exchange rate management where the CBN intervenes to stabilize the exchange rate within a band. Second, there is the Monetary Policy Committee (MPC) discharging price stability mandate through monetary policy rate (MPR) and third, there is free capital mobility (absence of capital controls).

Moving forward, it is expedient that sterilization (as monetary policy) in Nigeria can be more effective when free capital flows are reviewed in favour of exchange rate management. This translates to having 2 macroeconomic objectives out of 3 articulated by the M-F theory. In this context, the CBN may review its current macroeconomic policy objective (free capital mobility) to give room for introducing some CFMs as well as strengthening macroprudential policy measures $^{7}$ as recommended by the IMF and practised in Brazil and Indonesia (This is because these countries are EMDEs that share some features and level of development with Nigeria), to enhance and complement monetary policy sterilization of net foreign assets (You 2014).

\section{References}

Adrian, T. (2018). Policy responses to capital flows. Speech delivered at LIII Meeting of Governors of Latin America, Spain and the Philippines at the IMF-World Bank Annual Meetings in Bali, Indonesia, October 11. Retrieved from https://www.imf.org/en/News/Articles/2018/11/15/sp101118-policy-responses-to-capitalflows

Aizenman, J., Jinjarak Y., \& Park, D. (2010).Capital flows and economic growth in the era of financial integration and crisis, 1990-2010. National Bureau of Economic Research Working Paper No. 17502. https://www.nber.org/papers/w17502

Buscaghia, M. A. (2003). Sterilization of capital flows and balance of payments crises. Retrieved from https://core.ac.uk/download/pdf/7355218.pdf

Calvo, G. A., Leiderman, L., \& Reinhart, C.M., (1993). Capital inflows and real exchange rate appreciation in Latin America: The role of external factors. Staff Papers, 40 (1), 108-151.

Cardarelli, R., Elekdag, S., \& Kose, M. A. (2010). Capital inflows: Macroeconomic implications and policy responses. Economic Systems, 34 (4), 333-356.

\footnotetext{
${ }^{7}$ Macroprudential measures are policy measures for the financial system designed to tackle macroprudential risks and limit or neutralize the risks (systemic) from escalating to real economy. The measures include, among others, leverage caps over business cycle, counter-cyclical buffers, including provisions of Basel 111 etc.
} 
Chow, H. K. (2008). Managing capital flows: The case of Singapore. ADBI discussion paper 100. Tokyo: Asian Development Bank Institute. Retrieved from http://www.adbi.org/discussion-paper/2008/03/27/2514

Christensen, J. (2004).Capital inflows, sterilization, and commercial bank speculation: The case of the Czech Republic in the mid-1990s. (No. 2004-2218). International Monetary Fund.

Chung, C. P., Hwang, J \& Wang C. (2014). The effectiveness and sustainability of the sterilization policy in China. Economics Research International Volume 2014.

Djedaiet, A. \& Ayad H. (2017). Hard currency inflows and sterilization policy in Algeria: An ARDL approach. Theoretical and Applied Economics, XXIV, 3(612), 83-96.

Eichengreen, B., Mussa, M., Dell'Ariccia, G., Detragiache, E., Milesi-Ferretti, G. M., \& Tweedie, A. (1999). Liberalizing capital movements: Some analytical issues Retrieved from https://www.researchgate.net/publication/233667486/download

Engle, R. \& Granger, G. (1987). Co-integration and error correction: Representation, estimation and testing. Econometric, 55, 251-276.

Fleming, J. M. (1962). Domestic financial policies under fixed and under floating exchange rates. Staff Papers, 9(3), 369-485.

Frankel, J. A. (1994). Sterilization of money inflows: Difficult (Calvo) or easy (Reisen)? IMF Working Paper No. 94 (159).

Gallagher P. K., \& Tian, Y. (2017). Regulating capital flows in emerging markets: The IMF and the global financial crisis. Review of Development Finance, 7, 95-106

Glick, R., \& Hutchison, M. (2000). Foreign reserves and money dynamics with asset portfolio adjustment: International evidence. Journal of International Financial Markets, Institutions and Money, 10, 229-47

Haberer, L. S., \& Lux N. (2012). The pros and cons of capital controls. Economic Policy Paper.

Hashmi, M.S., Xu, C., Khan, M. M., Bashir, M., \& Ghazanfar, F. (2011). Monetary policy reaction function and sterilization of capital inflows: An analysis of Asian countries.. Asian Social Science, 7(9), pp. 19-32.

IMF (2011). Recent experiences in managing capital inflows-Cross-cutting themes and possible policy framework. IMF policy paper Washington, DC. Retrieved from http://www.imf.org/external/pp/longres.aspx ?id=4542

Pradhan, M., Balakrishnan, R., Baqir, R., Heenan, G., Nowak, S., Oner, C., \& Panth C., (2011). Policy responses to capital flows in emerging markets. IMF Staff Discussion Note. 
Johansen S., \& Juselius, K. (1990). Maximum likelihood estimation and inference on cointegration-with applications to the Demand for Money. Oxford Bulletin of Economics and Statistics, 52(2), 169-210.

Kawai, M., \& Takagi, S. (2008). A survey of the literature on managing capital inflows. ADB Institute Discussion Paper No. 100 Tokyo: Asian Development Bank Institute. Retrieved from:http://www.adbi.org/discussionpaper/2008/03/27/2514. managing.capital.inflows.lit.survey/

Khushk, A. G., Gilal, M. A., \& Taherani, A. (2015). Capital movements and sterilization policies in Pakistan. Grassroots, 49 (2), 1-12.

Knight, M. D. (2016). Capital flows to emerging market economies: Feast or famine forever? Centre for International Governance Innovation (CIGI) Papers No. 96.

Kouri, P. J., \& Porter, M. G. (1974). International capital flows and portfolio equilibrium. Journal of Political Economy, 82(3), 443-467.

Kwiatkowski, D. Phillips, P. C. B., Schmidt, P., \& Shin Y. (1992). Testing the null hypothesis of stationarity against the alternative of a unit root. Journal of Econometrics, 54 (1-3), 159-178

Lee, J. (1997). Sterilizing capital flows. Economic Issues, IMF (7).Retrieved from http://www.imf.org/external/pubs/ft/issues7/issue7.pdf

Moreno, R. (1996). Intervention, sterilization, and monetary control in Korea and Taiwan. Economic Review-Federal Reserve Bank of San Francisco, 3, 23.

Mundell, R. A. (1963). Capital mobility and stabilization policy under fixed and flexible exchange rates. The Canadian Journal of Economics and Political Science, 29 (4), 475-485.

Nar, M. (2014). Capital controls, new IMF policies and the practice of Turkey. American Journal of Economics, 4(6), 226-239. Retrieved from http://article.sapub.org/10.5923.j.economics.20140406.02.html

Nkoro, E., \& Uko, A. K. (2016). Autoregressive distributed lag (ARDL) co-integration technique: Application and interpretation. Journal of Statistical and Econometric Methods, 5 (4), 63-91

Okpanachi, U. M. (2012). An assessment of monetary policy response to capital inflows in Nigeria. CBN Journal of Applied Statistics, 3(2), 75-98. Retrieved from: https: //www.cbn.gov.ng/out/2013/sd/cbn\%20jas\%20volume\%203\%20number $\% 202$ article\%205.pdf 
Ouyang A. Y., \& Rajan R. S. (2005). Monetary sterilization in China since the 1990s: How much and how effective? Centre for International Economic Studies (CIES) Discussion Paper No. 0507

Pesaran, M. H., \& Shin, Y. (1998). An autoregressive distributed-lag modeling approach to co-integration analysis Econometric Society Monographs, 31, 371-413.

Pesaran, M. H., \& Shin, Y. (1999). An autoregressive distributed-lag modeling approach to co-integration analysis, In: Strom, S., Holly, A., Diamond, P. (Eds.), Centennial Volume of Rangar Frisch, Cambridge University Press.

Pesaran, M. H., Shin, Y. \& Smith, R. J. (2001). Bounds testing approaches to the analysis of level relationships. Journal of Applied Econometrics, 16(3), 289-326.

Proshare (2016). Scarcity Hits Parallel Market Due to High FX Demand. Online access @ https://www.proshareng.com/news/Forex/Scarcity-Hits-Parallel-Market-Dueto-High-FX-Demand/32442

Qayyum A., \& Khan M. A. (2003). Capital Flows and Money Supply: The Degree of Sterilisation in Pakistan. The Pakistan Development Review, Pakistan Institute of Development Economics, 42(4), 975-985.

Rajan, R. G., \& Subramanian, A. (2005). What undermines aids impact on Growth ? IMF Working Paper 05/126.

Reinsen, H. (1993a). The impossible trinity in South East Asia. International Economic Insights March/April

Reinsen, H. (1993b). Macroeconomic policies towards capital account convertibility, in Reisen H. and Fischer, B. (Eds.), Financial opening: policy issues and experiences in developing countries, OECD: Paris, pp. 43-55.

Takagi, S. \& Esaka, T. (2001). Sterilization and the capital inflow problem in East Asia, 1987-1997. In Regional and Global Capital Flows: Macroeconomic Causes and Consequences. NBER-EASE, 10, 197-226. University of Chicago Press. Online access @ http://www.nber.org/chapters/c10735

You, Y. (2014). Do capital controls enhance monetary independence? Review of Development Economics, 18(3), 475-489. Retrieved from https://onlinelibrary.wiley.com/doi/pdf/10.1111/rode.12097 


\section{Appendix 1: Stability Tests}

a) CUSUM Test for Stability of Parameters of Model Equation 4

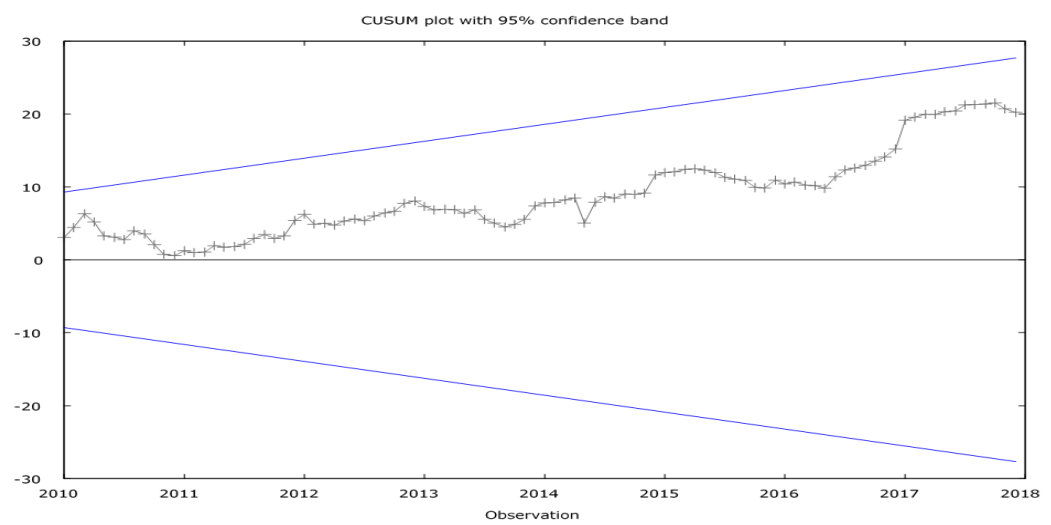

Figure 7: Cumulative Sum of Recursive Residuals (CUSUM) test for parameter stability The straight lines in Figure 7 represent critical bounds at 5\% significance level.

b) CUSUMSQ Test for Stability of Parameters of Model Equation 4,

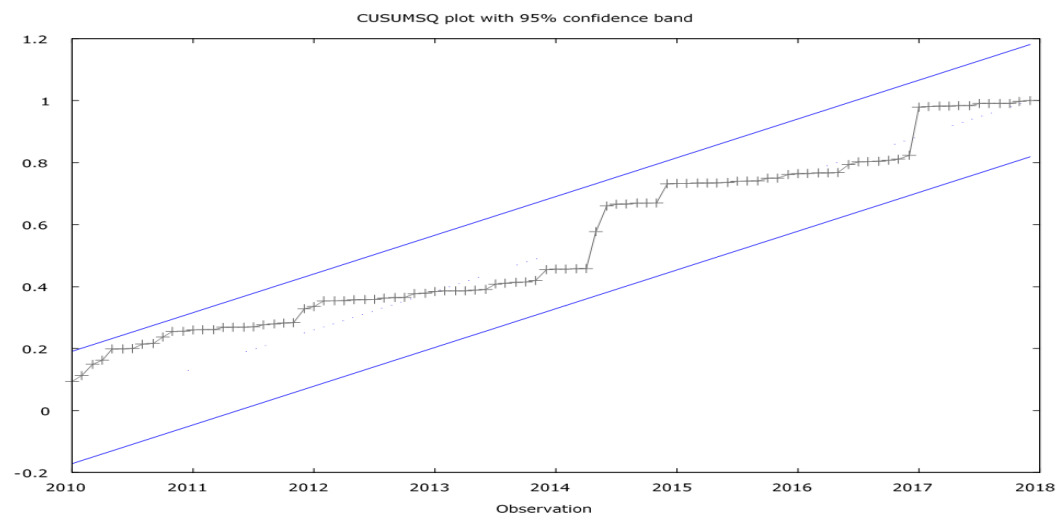

Figure 8: Cumulative Sum of Square of Recursive Residuals (CUSUMQ) Test for Stability of Parameters . The straight lines in Figure 8 represent critical bounds at 5\% significance level.

\section{Appendix 2: Diagnostic Tests}

\section{RESET test for specification}

Null hypothesis: specification is adequate

Test statistic: $F(2,94)=2.47639$

with $\mathrm{p}$-value $=\mathrm{P}(\mathrm{F}(2,94)>2.47639)=0.0895142$ 
An Assessment of the Effectiveness of Central Bank Sterilization on Capital Inflows in Nigeria

\section{Breusch-Pagan test for heteroskedasticity}

Null hypothesis: heteroskedasticity not present

Test statistic: $\mathrm{LM}=14.5911$

with $\mathrm{p}$-value $=\mathrm{P}($ Chi-square $(9)>14.5911)=0.102797$

\section{White's test for heteroskedasticity}

Null hypothesis: heteroskedasticity not present

Test statistic: $\mathrm{LM}=49.0392$

with $\mathrm{p}$-value $=\mathrm{P}($ Chi-square $(54)>49.0392)=0.665709$

\section{Test for normality of residual}

Null hypothesis: error is normally distributed

Test for null hypothesis of normal distribution:

Chi-square $(2)=42.222$ with p-value 0.00000 